\title{
Identification and utilization of actinobacteria for biocontrol of rice sheath blight pathogen, Rhizoctonia solani
}

\author{
SNEHAL J. SHINDE, S.K. PRASHANTHI AND P.U. KRISHNARAJ
}

\author{
Department of Biotechnology, College of Agriculture, University of Agricultural Sciences, DHARWAD (KARNATAKA) \\ INDIA \\ Email : prashanthi.sangam@gmail.com
}

\begin{abstract}
Sheath blight of rice is an important soil-borne fungal disease caused by Rhizoctonia solani. Isolation and exploitation of bioagents associated with rice offers a great opportunity for sustainable management of rice diseases. Actinomycetes were isolated from rice rhizosphere and isolates were putatively selected based on characteristic colony morphology. 16S rDNA and ARDRA confirmed their identification as actinobacteria. Isolates belonged either to Streptomyces spp. or Actinopolymorpha spp. Under in vitro condition, isolates IABT-A1, IABTA2, IABT-A3, IABT-A6, IABT-A7, IABT-A8 and IABT-A9 showed 98-100 per cent inhibition of Rhizoctonia solani, rice sheath blight pathogen. Further, five isolates were evaluated under glass house condition and the potent actinobacteria against rice sheath blight was identified. Among these isolates, IABT-A7 (Actinopoymorpha spp.) was most effective and application as seed treatment, soil and foliar spray was found most promising in terms of disease reduction and plant growth promotion. Actinopoymorpha spp. (IABT-A7) enhanced plant height, root length and root biomass in addition to reduced sheath blight infection in rice. This result indicates the role of actinobacteria isolate IABT-A7, as the probable stimulator of ISR (Induced Systemic Resistance) signaling pathway involved in plant disease resistance.
\end{abstract}

Key words : Rice, Rhizoctonia solani, Actinomycete, Biocontrol, Sheath blight

How to cite this paper : Shinde, Snehal J., Prashanthi, S.K. and Krishnaraj, P.U. (2014). Identification and utilization of Actinobacteria for biocontrol of rice sheath blight pathogen, Rhizoctonia solani. Asian J. Bio. Sci., 9 (2) : 227-233. 